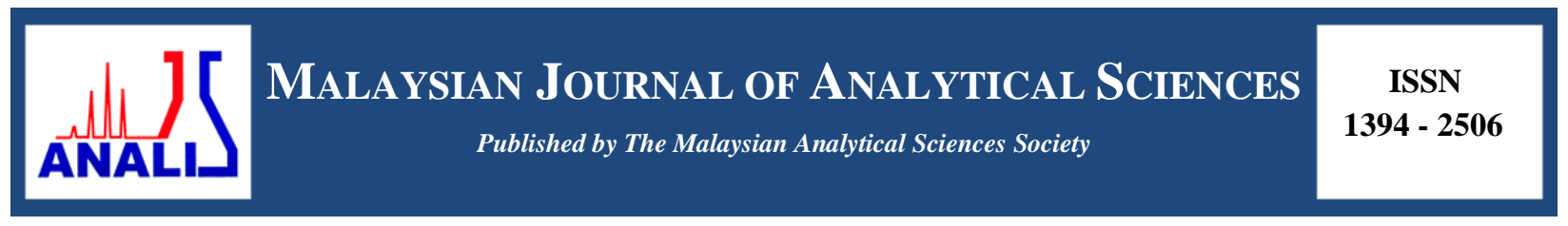

\title{
SURFACE MODIFICATION OF POLYETHERSULFONE MEMBRANE VIA UV-GRAFTING FOR FORWARD OSMOSIS TECHNOLOGY
}

\author{
(Modifikasi Permukaan Membran Polyetersulfon Melalui Cantuman-UV untuk Teknologi \\ Osmosis ke Hadapan)
}

\author{
Ahmad Fikri Hadi Abdul Rahman* and Mazrul Nizam Abu Seman \\ Faculty of Chemical \& Natural Resources Engineering, \\ Universiti Malaysia Pahang, 26300 Kuantan, Pahang, Malaysia \\ *Corresponding author: fikrihadi@gmail.com
}

Received: 16 April 2017; Accepted: 7 March 2018

\begin{abstract}
In this study, UV-grafting was used in surface modification of polyethersulfone membrane (UFPES50) for forward osmosis (FO) application. Using two parameters, namely monomer concentration (acrylic acid) and grafting time, the modified membrane was characterised by attenuated total reflectance-Fourier transform infrared (ATR-FTIR), field emission scanning electron microscope (FESEM) and contact angle. The membrane was evaluated for its water permeability, solute permeability, and structural parameter. The water permeability increases as the grafting parameters increases; however, at the highest (50 g/L) of monomer concentration, a sudden drop occurred due to the thickening of the grafted layer. Focusing on this monomer concentration, the grafting time was increased up to 60 minutes and it was successfully demonstrated that the modification using UV-grafting on PES membrane involved both effective grafting and chain scission. In addition, negative rejection on the modified membrane was observed.
\end{abstract}

Keywords: forward osmosis, effective grafting, negative retention, structural parameter

\begin{abstract}
Abstrak
Di dalam kajian ini, kaedah cantuman UV digunakan untuk mengubah membran polyetersulfon (UFPES50) untuk kegunaan aplikasi osmosis ke hadapan. Dua parameter digunakan iaitu kepekatan monomer (asid akrilik) dan masa cantuman. Pencirian bagi membran yang telah dimodifikasi dilakukan melalui spektroskopi transformasi infra merah Fourier- pantulan keseluruhan dikecilkan (ATR-FTIR), mikroskop imbasan elektron pancaran medan (FESEM) serta sudut sentuhan. Membran telah di nilai dari segi ketelapan air, ketelapan bahan larut dan struktur parameter. Ketelapan air meningkat dengan pertambahan percambahan parameter, tetapi pada kepekatan monomer yang tinggi $(50 \mathrm{~g} / \mathrm{L})$, telah berlaku perubahan yang mendadak. Dengan memberi fokus kepada kepekatan ini, masa cantuman ditingkatkan sehingga 60 minit. Hasil kajian berjaya membuktikan bahawa proses cantuman meliputi cantuman berkesan dan pemotongan rantaian. Selain daripada itu, di dapati terdapat penolakan negatif pada membran yang telah diubah suai.
\end{abstract}

Kata kunci: osmosis ke hadapan, cantuman berkesan, penolakan negatif, struktur parameter

\section{Introduction}

Access to clean water is crucial for all human being. As a result, advancement in water treatment technology is necessary. In the quest for a technology that can achieve better efficiency, longer life-cycle, limited operating area, as well as low capital and operating expenditure, forward osmosis (FO) was the breakthrough in replacing the conventional reverse osmosis (RO) process. In the FO process, it employs the natural osmotic pressure as its main 
driving force. It purifies water by facilitating water diffusion through the membrane while rejecting almost all dissolved and suspended constituents [1]. Three parameters are commonly employed in measuring the performance of FO system, namely pure water permeability (A), solute permeability (B), and structural parameter (S) which governs the transport phenomena across the membrane support layer.

There are many methods available to modify FO membranes to make them ideal candidates for designated separation processes. Surface modification has been proven to increase the water flux and hydrophilicity, decrease solute permeability, and increase the resistivity towards natural organic matter and chlorine attack [2]. Grafting is a process to add new properties of functionalities into a polymer. The term grafting is defined as the covalent bond between carbon-carbon bond between monomer or polymer with a substrate [3]. The grafting techniques include chemical, ultraviolet, ozone, plasma and atmospheric pressure plasma [4]. Among surface modifications, UVgrafting has attracted various researchers as it provides advantages in terms of its simplicity, usefulness, versatility and low cost [5]. Modification via UV-grafting technology has been widely used in various industries especially in packaging and coating-related field [6]. The grafting process involves an optimal selection comprising irradiation intensity, duration, $\mathrm{pH}$, and distance [7]. It is important to understand that in surface modification, hydrophilicity and roughness largely control the membrane fouling characteristics, while chemical, thermal, and mechanical stabilities determine the membrane durability under various environments [8]. This modification increases membrane surface hydrophilicity and shifts the membrane pore size distribution to a smaller size [9].

Polyethersulfone (PES) is one of the commonly used polymers in fabrication of ultrafiltration and microfiltration membranes. Advantages of this hydrophobic material are in its high mechanical, chemical and thermal stability due to the existence of aromatic hydrocarbon groups in the structure [10]. This polymer can generate several sites on the surface and on the pore wall because it is a photosensitive material. The aim of most previous researches involving UV-grafting technique was to add nanoparticle antifouling material [11], to add more layers using cross-linker [12, 13] and to focus on optimisation using response surface methodology (RSM) [14]. Most of the reported UV-grafted membranes are generally applied to pressure-based membranes (RO, NF, UF and MF) and they exhibited good performance. Therefore, this research paper reports on the potential use of UV-grafted in the FO application. It investigates the effect of grafting parameters (grafting time and monomer concentration) on the FO membrane.

\section{Materials and Methods}

The polyethersulfone ultrafiltration (UFPES50) membrane was purchased from AMFOR INC (China). Acrylic acid (Merck Chemicals) was used as monomer for UV-grafting. For membrane in the surface modification, the mercury lamp (UVP, 100W) was used as the UV-light source. Prior to surface modification, the membrane was immersed overnight and rinsed with pure water to remove its protective layer. Firstly, the membranes were immersed in 50 $\mathrm{mL}$ of different concentrations $(5-50 \mathrm{~g} / \mathrm{L})$ of acrylic acid and left under gentle stirring for 15 minutes. Next, the membrane undergoes surface modification under UV light at predetermined time while it is still fully immersed. The membranes were later taken out and rinsed with pure water to remove the unreacted compound. Finally, all the modified membranes were stored in new DI water for at least 1 day prior to use. The membrane water permeability (L/hr.m ${ }^{2}$.bar) and solute permeability were measured at different levels of pressure (1-8 bar) by using stirred cell (Sterlitech, HP4750). The water flux was calculated by using the following equation 1: $\left(J_{w}=\right.$ Permeate Volume/Area) where the water flux is $\left(\mathrm{L} / \mathrm{h} \cdot \mathrm{m}^{2}\right)$; the permeate volume is $(\mathrm{L})$; the effective membrane area is $\left(\mathrm{m}^{2}\right)$. For the solute permeability test, sodium chloride with $200 \mathrm{mg} / \mathrm{L}$ concentration was used. The concentration of the permeate and bulk solution was measured using conductivity meter. The pure water permeability, A, and solute permeability, B, was determined by using the following equations:

$$
\begin{aligned}
& A=\frac{K w}{\Delta P} \\
& B=J_{w}\left(\frac{1-R}{R}\right) \exp \left(-\frac{W_{w}}{k}\right)
\end{aligned}
$$

Rejection value was calculated from $\left(\mathrm{R}=1-C_{p} / C_{f}\right)$ where $C_{p}$ is the concentration of permeate while $C_{f}$ is the concentration of feed solution. 
In addition, lab-scale forward osmosis system was also used to determine the structural parameter, $\mathrm{S}$. In the FO experiment, $2000 \mathrm{~mL}$ of the draw solution $(1 \mathrm{M} \mathrm{NaCl})$ and the feed solution of pure water were prepared and used to carry out the FO process. The initial mass of feed solution was recorded and further readings were determined at an interval of 5 min until the process was accomplished in one hour. Then, the structural parameter, $\mathrm{S}$ value was determined by using;

$$
S=\frac{D_{s}}{h_{w}} \ln \left(\frac{B+A \pi D_{, f}}{B+H_{w}+A \pi F_{2} m}\right)
$$

where $D_{s}$ is the feed solution diffusivity of the draw solute, $\pi_{D, f}$ is the feed osmotic pressure of the draw solution and $\pi_{\mathrm{F}, \mathrm{m}}$ is the osmotic pressure at the membrane surface on the feed side (zero for pure water feed). We assume a constant diffusion coefficient of $\mathrm{NaCl}$ for the stated concentration used.

The morphology structure of the modified membrane was observed via a Field Emission Scanning Electron Microscope, FESEM (Jeol, JSM7800F) where the sample was fractured after being immersed in liquid nitrogen to get the cross-section view. For the surface chemistry, the hydrophilicity of the membrane was measured using contact angle (Geniometer) while Attenuated Total Reflection-Fourier Transform Infrared Spectroscopy (ATRFTIR) was used to detect the functional group.

\section{ATR-FTIR, contact angle and FESEM analysis}

\section{Results and Discussion}

The commercial ultrafiltration membrane was modified with different monomer concentration and irradiation time. The mechanism of surface modification starts when the phenoxyphenyl sulfone chromopores in the polyethersulfone chain absorb the UV-light. This results in the haemolytic cleavage of a carbon-sulphur bond at the sulfone linkage, yielding two radical sites at the end of the respective polymer chains [9]. These free radicals reacted with monomer solution to form chain of carboxylic group on the polymer trunk and leads to an increase in the hydrophilicity of the membrane [15]. To confirm the success of the modification via UV-grafting, the membrane was analysed using ATR-FTIR before and after modification as shown in Figure 1. New peaks appeared in ATRFTIR spectra of the modified membranes in comparison with those obtained for the unmodified membrane. As can be seen clearly, for the modified membrane, a new peak is formed at $1721 \mathrm{~cm}^{-1}$ (shown in the circle) which could be assigned to the new carboxyl group.

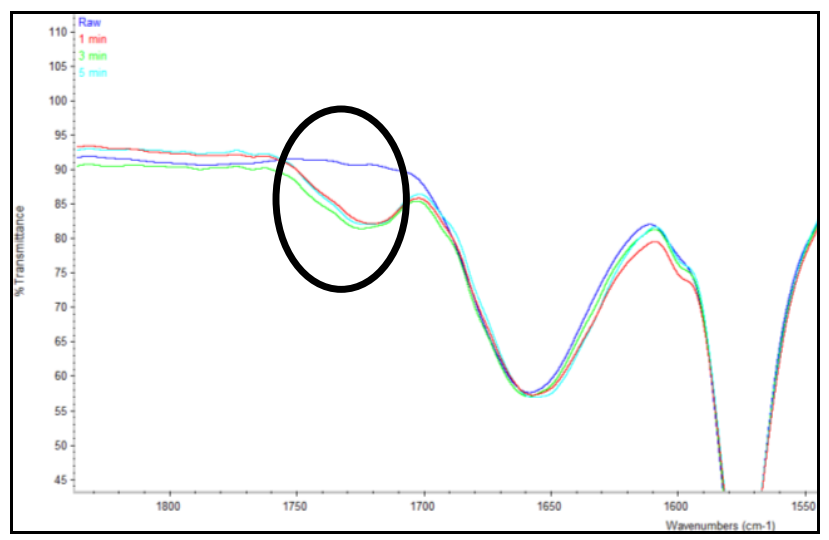

Figure 1. ATR-FTIR for modified and unmodified membranes at grafting time (1, 3 and 5 minutes)

Contact angle was commonly used to identify the hydrophilicity/hydrophobicity in membrane technology. Several factors affecting the morphology of a membrane, such as hydrophilicity, roughness, porosity, pore size, and its distribution affect the contact angle data [16]. The study on the hydrophobicity of PES is well documented by Zhao 
et al. [17] who reported that in most cases, the modified membranes will become more hydrophilic after modification. In this experiment, the unmodified membrane with a $59^{\circ}$ contact angle and $50 \mathrm{~g} / \mathrm{L}$ monomer concentration of acrylic acid is used. From Figure 2, the value in contact angle does not clearly indicate whether there is an increase or a decrease trend in hydrophilicity. The hydrophilicity of the modified membrane is increased if the value obtained is lower than the unmodified. However, only two samples were successful: the membranes grafted at 20 minutes and 60 minutes. In the overall surface modification, the contact angle does not provide a clear picture to indicate that the addition of carboxylic group on the membrane surface will increase the membrane hydrophilicity.

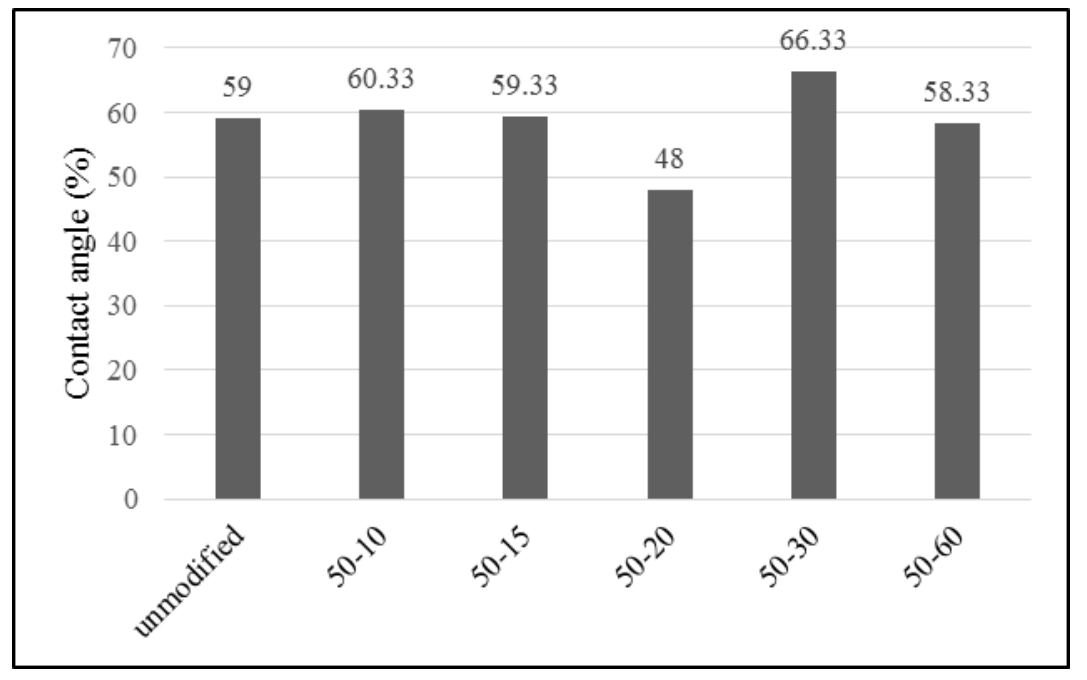

Figure 2. Hydrophilicity of the unmodified and modified membranes

The cross-section of the polyethersulfone membrane was characterised by FESEM as in Figure 3. One of the downsides in using the ultrafiltration to determine the cross section is that the support layer must be removed before any sample can be observed via FESEM. The support layer prevents the sample from getting fractured easily even after a prolonged time being immersed in liquid nitrogen. However, in this figure, the support layer is not visible as it is located at the bottom. In the unmodified membrane in (a), the active layer is $1.24 \mu \mathrm{m}$ and is formed in the production process. Compared with the modified membrane of 50AA-15min, the active layer has increased to 4.51 $\mu \mathrm{m}$. A uniform dense top layer is formed on the modified membrane and as can be observed, the uniform layer is made of interconnected holes and is restricting the initial pore size of the ultrafiltration membrane. It is believed to be the new polyacrylic layer with carboxyl functional group [18, 19]. This functional group provides negative charges and the hydrophilicity property of the modified membrane.
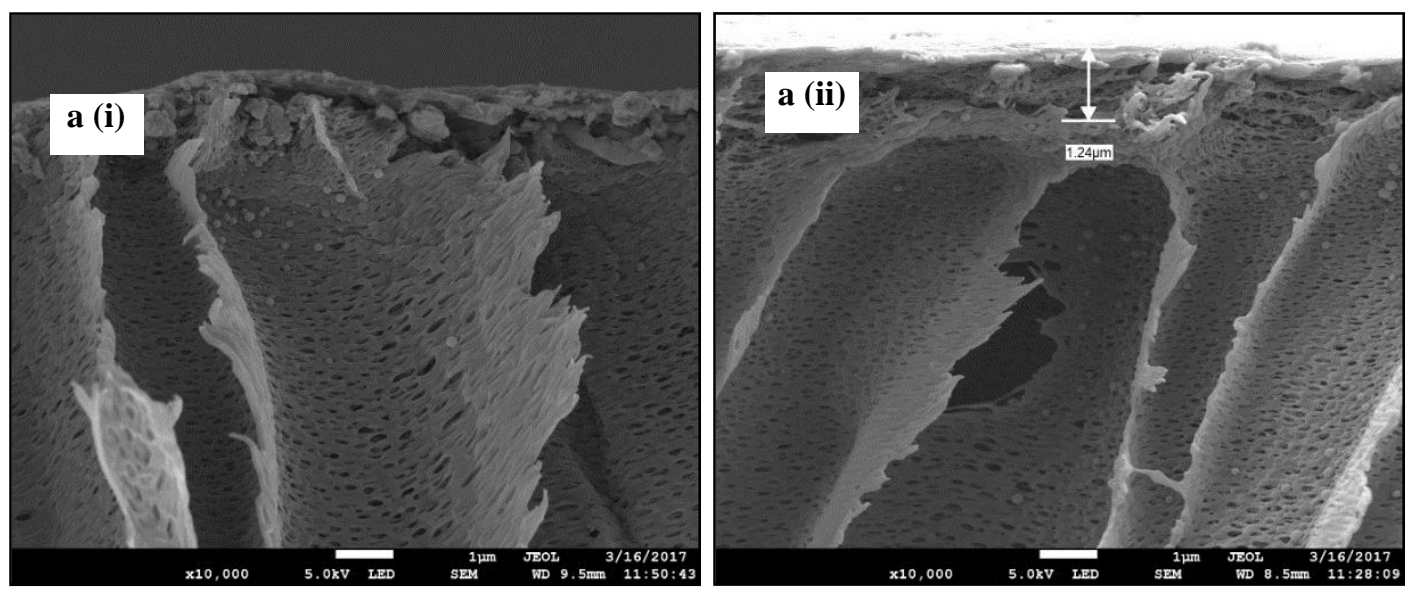

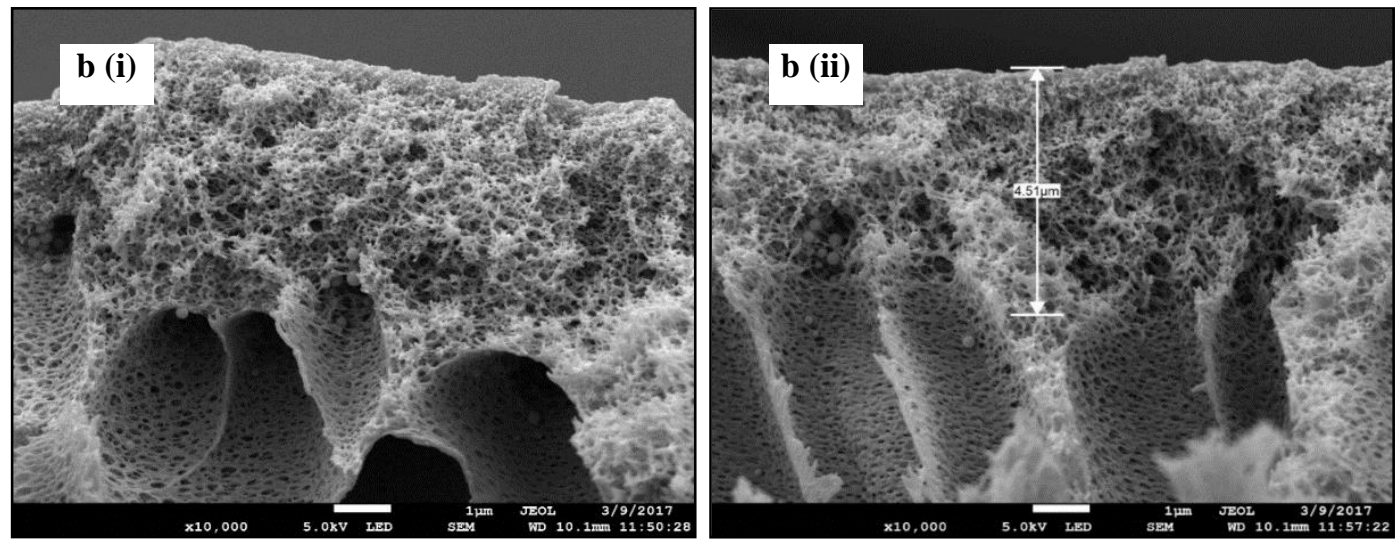

Figure 3. (a) unmodified and (b) modified membrane cross-section

\section{Water permeability}

The result of water permeability, $\mathrm{A}$, is shown in Table 1 . In the modification of the membrane, each of the monomer concentrations $(5,15,30$ and $50 \mathrm{~g} / \mathrm{L})$ was UV-grafted at different irradiation times $(1,3$ and 5 minutes). The unmodified UFPES50 membrane has the value of A at $98.87 \mathrm{~L} / \mathrm{hr}^{2} \mathrm{~m}^{2}$. bar. This value was obtained from the water flux and the pressure tested for up to 8 bars. In this paper, we use acrylic acid as the sole monomer, hence the effect of monomer size, chemical group, degree of polymerisation and surface coverage are remained constant [20]. This is with the assumption that the temperature during UV-grafting remains the same. From the Table 1, it can see that the water permeability increases with the increase in monomer concentration until it reaches a peak when monomer concentration used is at $30 \mathrm{~g} / \mathrm{L}$. A sudden drop in the water permeability can be observed when the monomer concentration used exceeds $30 \mathrm{~g} / \mathrm{L}$. The modified membranes have higher A value than the unmodified membranes except for $5 \mathrm{AA} / 1 \mathrm{~min}, 50 \mathrm{AA} / 3 \mathrm{~min}$ and $50 \mathrm{AA} / 5 \mathrm{~min}$.

Table 1. Water permeability of the unmodified and modified membranes using different acrylic acid (AA) concentrations and different UV-irradiation times (T)

\begin{tabular}{lccc}
\hline Membrane & AA $(\mathbf{g} / \mathbf{L})$ & $\mathbf{T}(\mathbf{m i n})$ & $\mathbf{A}\left(\mathbf{L} / \mathbf{h r} . \mathbf{m}^{\mathbf{2}}\right.$.bar $)$ \\
\hline Unmodified & - & - & 98.87 \\
5AA-1 & 5 & 1 & 97.97 \\
5AA-3 & 5 & 3 & 108.48 \\
5AA-5 & 5 & 5 & 122.31 \\
15AA-1 & 15 & 1 & 131.66 \\
15AA-3 & 15 & 3 & 152.21 \\
15AA-5 & 15 & 5 & 121.83 \\
30AA-1 & 30 & 1 & 161.16 \\
30AA-3 & 30 & 3 & 171.23 \\
30AA-5 & 30 & 5 & 182.65 \\
50AA-1 & 50 & 1 & 114.16 \\
50AA-3 & 50 & 3 & 93.40 \\
50AA-5 & 50 & 5 & 97.85 \\
\hline
\end{tabular}


$\mathrm{Xi}$ et al. [21] has also observed that the grafting yield increased with the increase in monomer concentration except at lower concentration. Acrylic acid is a strong acid and it provides negative charges to the modified membrane as the formation of carboxylic group in the functional group makes it more hydrophilic. The modified membrane 5AA$1 \mathrm{~min}\left(97.97 \mathrm{~L} / \mathrm{m}^{2}\right.$.hr.bar) is believed to have insufficient effective grafting as it was conducted in low monomer concentration and short grafting time. The original functional group at the membrane surface managed to either repel the negative charges from the monomer or the number of energy received by phenoxyphenyl sulfone chromopores was below the minimal energy to form free radicals. At $50 \mathrm{~g} / \mathrm{L}$ of monomer concentration, the water permeability shows a great decline in all tested grafting times. The highest monomer concentration might lead to a competitive effective grafting at the membrane surface. Similar trend is also observed by Bilongo et al. [22] where the effective grafting increases with the increase of monomer concentration. The author justifies the relationships of kinetic in photo-polymerisation where a good grafting condition must be derived from a high monomer concentration and strong dose of UV energy. This phenomenon leads to the thickening of the grafted layer.

Further experimental works has been conducted to evaluate the sudden drop in water permeability for monomer concentration of $50 \mathrm{~g} / \mathrm{L}$ as shown in Figure 4 below. In general, the value of A shows a reduction with the increase of grafting time as shown by the trendline. The trendline was generated after the experiment was conducted under 8 different grafting times (minute). From the figure, A shows a decreasing value as the grafting time increases. However, as the grafting time exceeds 15 minutes, the water permeability shows an increasing value. The decrease in the water flux value does not correlate well with the progressive increase in the grafting time. Interestingly, the polymerisation mechanism in membrane surface involved both effective grafting and chain scission processes instead of a steady growth of polymer chain [23]. According to Mansourpah and Momeni Habili, the longer UV radiation period lead to the enhancement in the polymerisation degree before obtaining a denser thin layer [24]. Moreover, the reduction of water permeability after modification was also observed by Yu et al. [25]. The polyethersulfone membrane was modified via UV- grafting with the usage of an initiator to improve antifouling property. The authors claimed that the reduction in water permeability was due to the formation of grafted material which had narrowed down the pore size. Similar result was also obtained by Taniguchi and Belfort [26] which suggests that water permeability declines with the increase of grafting time. The formation of grafted material that leads to pore plugging implies a formation of gel layer on the modified surface. At grafting time of 15 minutes, the modified membrane impeded water movement. When a maximum pressure of 8 bar was used, however, the water permeability was only at $1.13 \mathrm{~L} / \mathrm{hr} \cdot \mathrm{m}^{2}$.bar. The trend of effective grafting increases with the increase of grafting time applied in the first 15 minutes.

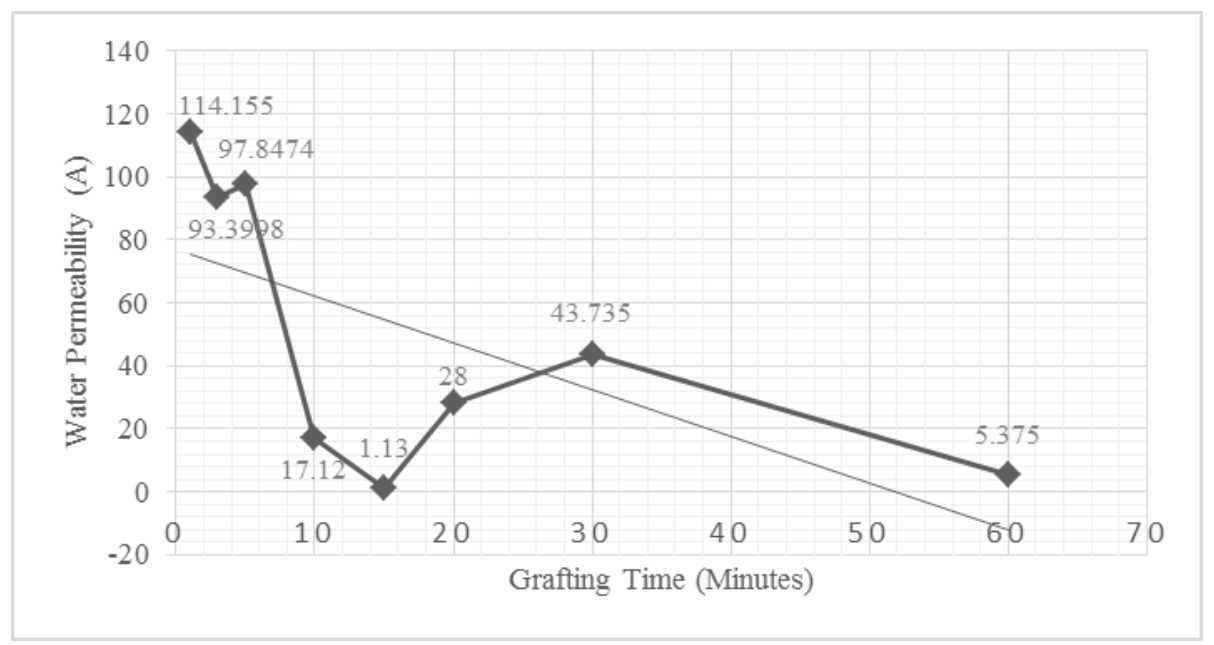

Figure 4. Water permeability for $50 \mathrm{~g} / \mathrm{L}$ of monomer concentration 
As the grafting time starts to increase from 15 minutes onwards, the water permeability starts to increase from 1.13 $\mathrm{L} / \mathrm{hr} . \mathrm{m}^{2}$.bar, $28 \mathrm{~L} / \mathrm{hr} \cdot \mathrm{m}^{2}$.bar and $43 \mathrm{~L} / \mathrm{hr}^{2} \mathrm{~m}^{2}$.bar. It is suggested that the mechanism that occurred between grafting time of 15 minutes and 30 minutes is chain scission. If chain scission is considered as the main reason for the increase in water permeability, the modified membrane with longer grafting time can be explained as in Figure 5.

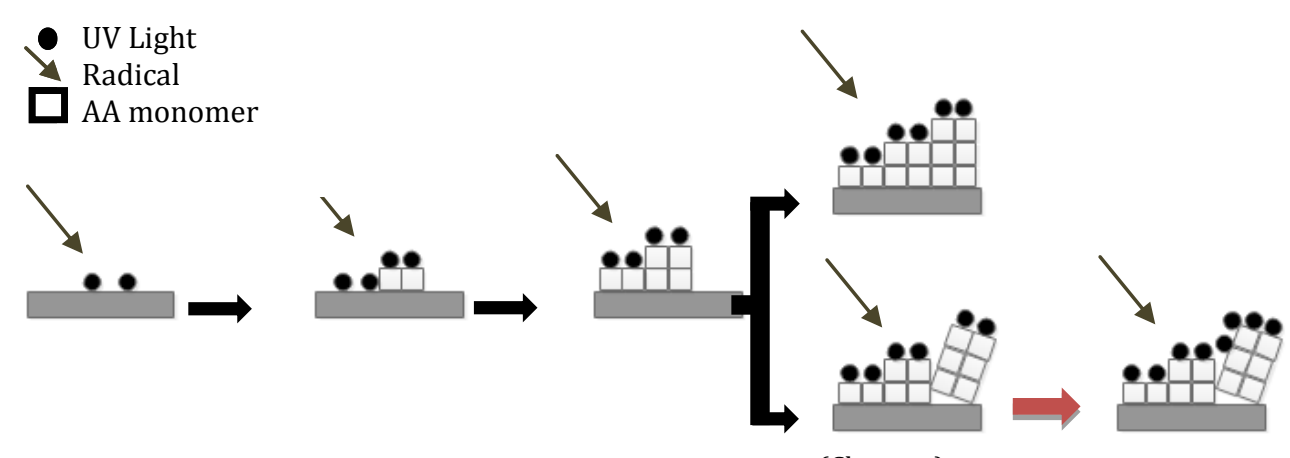

(Cleavage)

Figure 5. Proposed process on PES membrane surface. Modified from Taniguchi et al. [27].

At the area where the cleavage occurred, the membrane surface is exposed directly to the feed solution which leads to the increase in water permeability. Garcia et al. [5] defines this scenario as the deterioration of membrane after a membrane exceeds a certain grafting parameter. As the chain scission occurs more rapidly at 30 minutes of grafting time, the water permeability increases. The effect of degradation on PES due to irradiation is unavoidable. This evidence is supported by Taniguchi et al. [27] who has shown that the grafting time leads to an increase in pore size. This author identified the trends in effective grafting or chain scission by measuring the degree of grafting (DG) using ATR-FTIR. At 60 minutes of grafting time, the value of A reduces to $5.3 \mathrm{~L} / \mathrm{hr} . \mathrm{m}^{2}$.bar. It is suggested that the grafting occurred at the cleavage of polymer chains to form a new layer. The phenomenon is relatively similar to the usage of a crosslinker such as glutaraldehyde (GA) in the formation of new layers on top of the previous layer. For example, Liu et al. [28] studied the usage of crosslinker and its effect on modified membrane that leads to reduction in pore size, increase in hydrophilicity and lowering of surface charge.

\section{Solute permeability}

Figure 6 shows the value of solute permeability using $50 \mathrm{~g} / \mathrm{L}$ of acrylic acid against time. The experiment is conducted using $200 \mathrm{ppm}$ of sodium chloride $(\mathrm{NaCl})$. As can be seen, the solute permeability of the modified membrane allows a normal reaction only in the first 3 samples where the grafting time was at 1 minute, 3 minutes and 5 minutes, respectively. As the grafting time was increased from 10 minutes onwards, the solute permeability began to record negative values. The conductivity meter recorded a higher value in the permeate solution compared to the feed solution. To obtain a qualitative data, the salute permeability test was conducted using the samples that were previously used in water permeability analysis.

As the grafting time starts to increase from 10 minutes onwards, the solute permeability starts to decrease from -7.7 $\times 10^{-4} \mathrm{~ms}^{-1}$ and the values remain on the negative side as the grafting time reaches 60 minutes. This phenomenon is identified as negative retention. Negative retention is the existence of "preferable" material that can pass through the membrane layer [29] regardless of its size. In other words, the modified membranes have an interest in transporting selective material or in this research, transporting the monovalent salt; sodium chloride $(\mathrm{NaCl})$. This halophile property was detected on the modified membrane and to the best of our knowledge this is the first-time negative retention is utilised in FO application. Similar trends have also been identified by Vatanpour et al. [30] by using $\mathrm{NaCl}$, sodium sulphate $\left(\mathrm{Na}_{2} \mathrm{SO}_{4}\right)$ and magnesium sulphate $\left(\mathrm{MgSO}_{4}\right) . \mathrm{NaCl}$ in the feed solution has high interaction with the membrane material and consequently, becomes preferential transport [29]. According to Schaep et al. [31] 
back in $2001, \mathrm{NaCl}$ is a single salt and this characteristic is suitable in determining the membrane charges. In the extended Nersk-Plack equation, the equation represents the transport mechanism involving diffusion, electric field gradient and convection. The existence of negative rejection in $\mathrm{NaCl}$ showed that the behaviour of the modified membranes could be classified by a combination of diffusion and Donnan exclusion mechanism [32]. Donnan exclusion in this context is defined as the reduction of ions in the feed solution due to the presence of fixed carboxylic group bearing the same sign as the mobile ions. The rejection of a charged solute depends on the pore radius of the effective membrane and the two electrical parameters, namely the effective membrane charge density and the dielectric exclusion energy barrier [33]. Furthermore, this charged solute is dependent on the ionic strength, the valence of the solutes and the concentration of the feed solution [31, 34]. It is quite impossible to differentiate which ions penetrate more in the modified membrane since the flux for $\mathrm{Na}^{+}$and $\mathrm{Cl}^{-}$were nearly equimolar [35]. At a different angle, the interaction between carboxylic group on the membrane surface and the $\mathrm{NaCl}$ feed solution are either by dissociation of functional groups or adsorption of ions from the solutions [36], causing the ions in the feed solution to be attracted to the permeate solution.

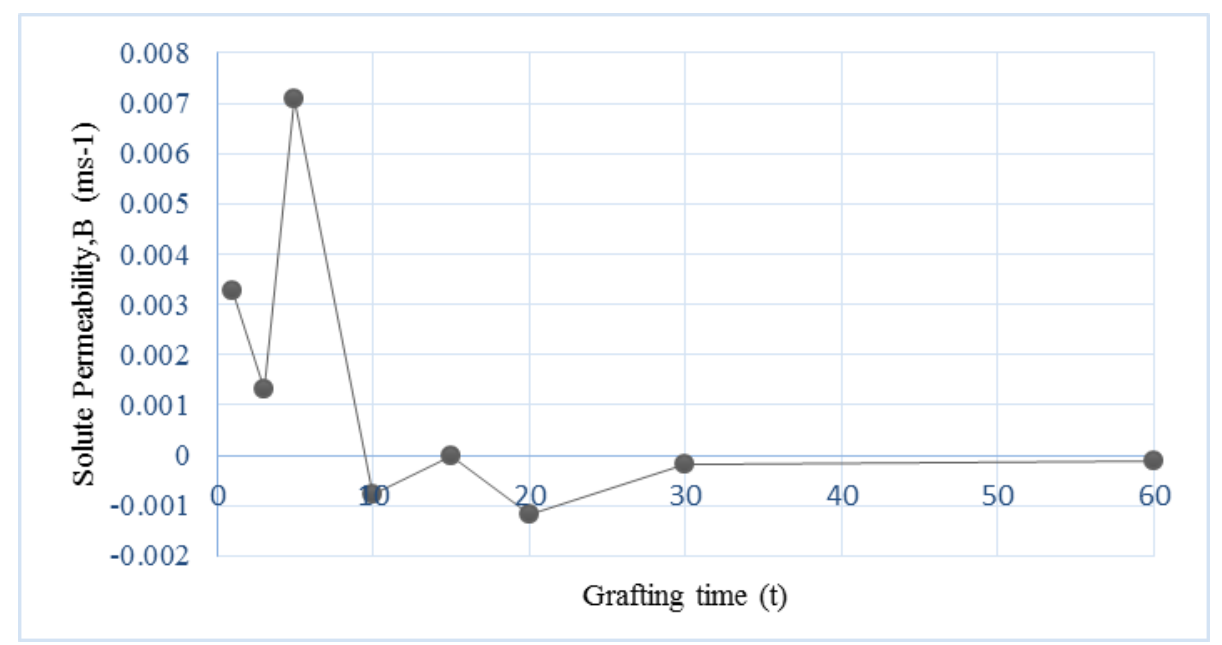

Figure 6. Solute permeability of the modified membrane at $50 \mathrm{~g} / \mathrm{L}$ of monomer concentration

\section{Structural parameter}

The membrane structural parameter, $\mathrm{S}$, is an intrinsic membrane parameter used to determine the degree of internal concentration polarization (ICP) in the porous support of the membrane [38]. It is useful in quantifying the mass transport length scale across the membrane support layer [39]. Hence, the aim of having a surface modification is to lower the value of structural parameter. In the solute permeability, it was found that the carboxylic group on the membrane surface causes a negative rejection as the grafting time increases, which indicates that the diffusion transport of salts within the membrane plays a crucial role in regressing the FO processes. Since the negative rejection starts to develop as the grafting time increases from 10 minutes onwards, the measurement of structural parameter is only applicable with samples grafted at 1, 3 and 5 minutes. From Table 2, the highest value of $S$ was observed for unmodified UFPES (54 x $\left.10^{-4} \mathrm{~m}\right)$ while all the UV-grafted membranes exhibited a lower value of S. It is noted that under minimal modification $(5 \mathrm{AA}-1 \mathrm{~min})$, the value decreases to $3.1 \mathrm{x} 10^{-4} \mathrm{~m}$ which shows that surface modification on PES membrane via UV-grafting has great potential and is comparable with the commercial CTA membrane. However, the performance of the modified membrane in Table 2 contradicts the expected result. From the table, it is observed that as the grafting parameter increases, the value of $\mathrm{S}$ increases. For example, for the modification using $30 \mathrm{~g} / \mathrm{L}$ of monomer concentration, the values of $\mathrm{S}$ obtained are $1.5 \times 10^{-4} \mathrm{~m}, 3.0 \times 10^{-4} \mathrm{~m}$ and $12 \mathrm{x}$ $10^{-4} \mathrm{~m}$ while at 5 minutes of grafting time, the values obtained are $2.7 \times 10^{-4} \mathrm{~m}, 4.5 \times 10^{-4} \mathrm{~m}, 12 \times 10^{-4} \mathrm{~m}$, and $13 \mathrm{x}$ $10^{-4} \mathrm{~m}$. The structural parameter value increases due to the decrease in water permeability and the low value of solute permeability. In general, the $\mathrm{S}$ values for most of our modified membranes are relatively in good agreement with the commercial CTA membrane $\left(4.27 \times 10^{-4} \mathrm{~m}\right)$. 
Table 2. Performance characteristics of the prepared UFPES membranes. Structural parameter measured using FO setup while water permeability, A and solute permeability, B from RO setup

\begin{tabular}{|c|c|c|c|c|c|c|}
\hline \multicolumn{2}{|c|}{ Sample } & \multirow{2}{*}{ 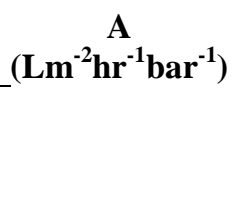 } & \multirow{2}{*}{$\underset{\left(\mathbf{x} 10^{-3} \mathrm{~ms}^{-1}\right)}{\mathrm{B}}$} & \multirow{2}{*}{$\underset{\left(10^{-3}\right)}{\mathbf{R}}$} & \multirow{2}{*}{$\begin{array}{c}\mathbf{J}_{\mathbf{w}, \mathbf{F O}} \\
\left(\mathbf{L m}^{-2} \mathbf{h} \mathbf{r}^{-1}\right)\end{array}$} & \multirow{2}{*}{$\underset{\left(10^{-4} \mathrm{~m}\right)}{\mathrm{S}}$} \\
\hline $\begin{array}{c}\mathbf{A A} \\
\begin{array}{c}\text { Concentration } \\
(\mathrm{g} / \mathrm{L})\end{array}\end{array}$ & $\begin{array}{l}\text { Grafting } \\
\text { time (min) }\end{array}$ & & & & & \\
\hline- & - & 98.87 & $7.4 \times 10^{-3}$ & 1.5 & 3.81 & 54 \\
\hline 5 & 1 & 98.0 & 3.4 & 3.94 & 4.0 & 3.1 \\
\hline 5 & 3 & 108.5 & 3.2 & 4.4 & 4.3 & 2.3 \\
\hline 5 & 5 & 122.3 & 3.1 & 4.65 & 4.2 & 2.7 \\
\hline 15 & 1 & 131.7 & 6.3 & 2.28 & 2.3 & 2.7 \\
\hline 15 & 3 & 152.2 & 3.8 & 3.78 & 4.8 & 2.4 \\
\hline 15 & 5 & 121.8 & 1.6 & 9.05 & 4.4 & 4.5 \\
\hline 30 & 1 & 161.2 & 8.0 & 1.80 & 4.1 & 1.5 \\
\hline 30 & 3 & 171.2 & 3.4 & 4.13 & 4.5 & 3.0 \\
\hline 30 & 5 & 182.6 & 1.0 & 1.31 & 3.0 & 12 \\
\hline 50 & 1 & 114.2 & 3.3 & 4.2 & 2.3 & 4.4 \\
\hline 50 & 3 & 93.4 & 1.3 & 1.02 & 3.1 & 6.1 \\
\hline 50 & 5 & 97.8 & 7.1 & 1.91 & 3.4 & 13 \\
\hline $\begin{array}{c}\text { Commercial } \\
\text { CTA membrane } \\
\text { [37] }\end{array}$ & & & & & & 4.27 \\
\hline
\end{tabular}

\section{Conclusion}

Surface modification via UV-grafting was successfully conducted as indicated by the new formation of carboxylic group on the polyethersulfone membrane. The addition of the hydrophilic material affects not only the water permeability and solute permeability but also the structural parameter. By lowering the structural parameter, it will eventually lower the internal concentration polarisation (ICP) which is one of the main problems faced in FO technology. The process of adding more hydrophilic layer onto the membrane surface will lead to the negative retention mechanism. It is suggested that this surface modification undergo optimisation process using response surface methodology (RSM) to achieve an optimal membrane in FO technology. Moreover, the interaction between carboxylic groups in a single layer is differentiated from those in a multilayer through the usage of photo initiator and cross linker.

\section{Acknowledgement}

The authors are grateful for the research financial support by Universiti Malaysia Pahang under the Postgraduate Research Grant Scheme (PGRS 160336) and the Ministry of Higher Education Malaysia for MyPhD and FRGS grant (RDU160127).

\section{References}

1. Cath, T., Childress, A. and Elimelech, M. (2006). Forward osmosis: Principles, applications, and recent developments. Journal of Membrane Science, 281(1-2): 70-87.

2. Kochkodan, V. and Hilal, N. (2015). A comprehensive review on surface modified polymer membranes for biofouling mitigation. Desalination, 356 (1): 187-207. 
3. Ng, L. T., Garnett, J. L., Zilic, E. and Nguyen, D. (2001). Effect of monomer structure on radiation grafting of charge transfer complexes to synthetic and naturally occurring polymers. Radiation Physics and Chemistry, 62(1): 89-98.

4. Kim, S. M. (2013). Surface nanostructuring of polysulfone membranes by atmospheric pressure plasmainduced graft polymerization (APPIGP). Thesis of Master Degree, University of California, USA.

5. Garcia-Ivars, J., Iborra-Clar, M. I., Alcaina-Miranda, M. I. Mendoza-Roca, J. A. and Pastor-Alcañiz, L. (2016). Surface photomodification of flat-sheet PES membranes with improved antifouling properties by varying UV irradiation time and additive solution pH. Chemical Engineering Journal, 283(1): 231-242.

6. He, D., Susanto, H. and Ulbricht, M. (2009). Photo-irradiation for preparation, modification and stimulation of polymeric membranes. Progress in Polymer Science, 34(1): 62-98.

7. Zhao, C., Nie, S., Tang, M. and Sun, S. (2011). Polymeric pH-sensitive membranes-A review. Progress in Polymer Science, 36(11): 1499-1520.

8. Yin, J. and Deng, B. (2015). Polymer-matrix nanocomposite membranes for water treatment. Journal of Membrane Science, 479(1): 256-275.

9. Abu Seman, M. N., Khayet, M., Ali, Z. I. and Hilal, N. (2010). Reduction of nanofiltration membrane fouling by UV-initiated graft polymerization technique. Journal of Membrane Science, 355(1): 133-141.

10. Ng, L. Y., Ahmad, A. and Mohammad, A. W. (2013). Alteration of polyethersulphone membranes through UVinduced modification using various materials: A brief review. Arabian Journal of Chemistry, 10(2): 1821-1834.

11. Garcia-Ivars, J., Iborra-Clar, M. I., Alcaina-Miranda, M. I., Mendoza-Roca, J. A. and Pastor-Alcañiz, L. (2014). Development of fouling-resistant polyethersulfone ultrafiltration membranes via surface UV photografting with polyethylene glycol/aluminum oxide nanoparticles. Separation and Purification Technology, 135(1): 88-99.

12. Peeva, P. D., Pieper T. and Ulbricht, M. (2010). Tuning the ultrafiltration properties of anti-fouling thin-layer hydrogel polyethersulfone composite membranes by suited crosslinker monomers and photo-grafting conditions. Journal of Membrane Science, 362(1-2): 560-568.

13. Setiawan, L., Wang, R., Tan, S., Shi, L. and Fane, A. G. (2013). Fabrication of poly(amide-imide)polyethersulfone dual layer hollow fiber membranes applied in forward osmosis by combined polyelectrolyte cross-linking and depositions. Desalination, 312(1): 99-106.

14. Chung, Y. T., Ng, L. Y. and Mohammad, A. W. (2014). Sulfonated-polysulfone membrane surface modification by employing methacrylic acid through UV-grafting: Optimization through response surface methodology approach. Journal of Industrial and Engineering Chemistry, 20(4): 1549-1557.

15. Deng, B., Li, J., Hou, Z., Yao, S., Shi, L., Liang, G. and Sheng, K. (2008). Microfiltration membranes prepared from polyethersulfone powder grafted with acrylic acid by simultaneous irradiation and their $\mathrm{pH}$ dependence. Radiation Physics and Chemistry, 77(7): 898-906.

16. Li, S. S., Xie, Y., Xiang, T., Ma, L., He, C., Sun, S. D. and Zhao, C. S. (2016). Heparin-mimicking polyethersulfone membranes - hemocompatibility, cytocompatibility, antifouling and antibacterial properties. Journal of Membrane Science, 498(1): 135-146.

17. Zhao, C., Xue, J., Ran, F. and Sun, S. (2013). Modification of polyethersulfone membranes - A review of methods. Progress in Materials Science, 58(1): 76-150.

18. Van der Bruggen, B. (2009). Chemical modification of polyethersulfone nanofiltration membranes: A review. Journal of Applied Polymer Science, 114(1): 630-642.

19. Wang, D., Zou, W., Li, L., Wei, Q., Sun, S. and Zhao, C. (2011). Preparation and characterization of functional carboxylic polyethersulfone membrane. Journal of Membrane Science, 374(1): 93-101.

20. Kato, K., Uchida, E., Kang, E. T., Uyama, Y. and Ikada, Y. (2003). Polymer surface with graft chains. Progress in Polymer Science, 28(2): 209-259.

21. Wei, X., Wang, R., Li, Z. and Fane, A. G. (2006). Development of a novel electrophoresis-UV grafting technique to modify PES UF membranes used for NOM removal. Journal of Membrane Science, 273(1): 47-57.

22. Bilongo, T. G., Remigy, J. C. and Clifton, M. (2010). Modification of hollow fibers by UV surface grafting. Journal of Membrane Science, 364(1): 304-308.

23. Kuroda, S. I., Nagura, A., Horie, K. and Mita, I. (1989). Degradation of aromatic polymers-III. Crosslinking and chain scission during photodegradation of polysulphones. European Polymer Journal, 25(6): 621-627.

24. Mansourpanah, Y. and Momeni Habili, E. (2013). Preparation and modification of thin film PA Membranes with improved antifouling property using acrylic acid and UV irradiation. Journal of Membrane Science, 342(1-2): 158-166. 
25. Yu, H., Cao, Y., Kang, G., Liu, J., Li, M. and Yuan, Q. (2009). Enhancing antifouling property of polysulfone ultrafiltration membrane by grafting zwitterionic copolymer via UV-initiated polymerization. Journal of Membrane Science, 342(1-2): 6-13.

26. Taniguchi, M. and Belfort, G. (2004). Low protein fouling synthetic membranes by UV-assisted surface grafting modification: Varying monomer type. Journal of Membrane Science, 231(1-2): 147-157.

27. Taniguchi, M., Pieracci, J., Samsonoff, W. A. and Belfort, G. (2003). UV-assisted graft polymerization of synthetic membranes: Mechanistic studies. Chemistry of Materials, 15(20): 3805-3812.

28. Liu, C., Shi, L. and Wang, R. (2015). Crosslinked layer-by-layer polyelectrolyte nanofiltration hollow fiber membrane for low-pressure water softening with the presence of $\mathrm{SO}_{4}{ }^{2-}$ in feed water. Journal of Membrane Science, 486(1): 169-176.

29. Volkov, A., Yushkin, A., Kachula, Y., Khotimsky, V. and Volkov, V. (2014). Application of negative retention in organic solvent nanofiltration for solutes fractionation. Separation and Purification Technology, 124(1): 4348.

30. Vatanpour, V., Madaeni, S. S., Moradian, R., Zinadini, S. and Astinchap, B. (2011). Fabrication and characterization of novel antifouling nanofiltration membrane prepared from oxidized multiwalled carbon nanotube/polyethersulfone nanocomposite. Journal of Membrane Science, 375(1): 284-294.

31. Schaep, J., Vandecasteele, C., Wahab Mohammad, A. and Richard Bowen, W. (2001). Modelling the retention of ionic components for different nanofiltration membranes. Separation and Purification Technology, 22(1): 169-179.

32. Bhanushali, D., Kloos, S. and Bhattacharyya, D. (2002). Solute transport in solvent-resistant nanofiltration membranes for non-aqueous systems: Experimental results and the role of solute-solvent coupling. Journal of Membrane Science, 208(1): 343-359.

33. Qiu, C., Zhang, Q. T. N. L. and Ping, Z. (2006). Nanofiltration membrane preparation by photomodification of cardo polyetherketone ultrafiltration membrane. Separation and Purification Technology, 51(3): 325-331.

34. Nilsson, M., Trägårdh, G. and Östergren, K. (2008). The influence of pH, salt and temperature on nanofiltration performance. Journal of Membrane Science, 312(1): 97-106.

35. Phillip, W. A., Yong, J. S. and Elimelech, M. (2010). Reverse draw solute permeation in forward osmosis: Modeling and experiments. Environmental Science and Technology, 44(13): 5170-5176.

36. Elimelech, M., Chen, W. H. and Waypa, J. J. (1994). Measuring the zeta (electrokinetic) potential of reverse osmosis membranes by a streaming potential analyzer. Desalination, 95(3): 269-286.

37. Achilli, A., Cath, T. Y. and Childress, A. E. (2010). Selection of inorganic-based draw solutions for forward osmosis applications. Journal of Membrane Science, 364(1): 233-241.

38. Park, M., Lee, J. J., Lee, S. and Kim, J. H. (2011). Determination of a constant membrane structure parameter in forward osmosis processes. Journal of Membrane Science, 375 (1-2): 241-248.

39. Tiraferri, A., Yip, N. Y., Straub, A. P., Romero-Vargas Castrillon, S. and Elimelech, M. (2013). A method for the simultaneous determination of transport and structural parameters of forward osmosis membranes. Journal of Membrane Science, 444(1): 523-538. 